Available online on 15.05.2019 at http://ujpr.org
Universal Journal of Pharmaceutical Research
An International Peer Reviewed Journal
Open access to Pharmaceutical research is an open access article distributed under the terms of the Creative Commons Attribution-Non
Commercial Share Alike 4.0 License which permits unrestricted non commercial use,
provided the original work is properly cited
Volume 4, Issue 2, 2019

\title{
PREVALENCE AND GENOTYPING OF HEPATITIS C VIRUS IN HEMODIALYSIS PATIENTS AND EVALUATION OF HCV-CORE ANTIGEN TEST IN SCREENING PATIENTS FOR DIALYSIS IN SANA'A CITY, YEMEN Samira H Hanash ${ }^{1}$, Hassan A. Al-Shamahy $^{2 *}$ (D) Mohammed Hussein Saleh Bamshmous ${ }^{2}$ (D) \\ ${ }^{I}$ Medical Microbiology, Faculty of Medicine and Health Sciences, Taiz University, Republic of Yemen. \\ ${ }^{2}$ Medical Microbiology and Clinical Immunology, Faculty of Medicine and Health Sciences, Sana'a University, Republic of Yemen.
}

\section{ABSTRACT}

Objective: Hepatitis C virus infection is a constant worldwide public health concern. The prevalence of HCV infection is higher in patients on chronic haemodialysis (HD) than in the general population. Despite the control of blood products, hepatitis $\mathrm{C}$ virus transmission is still being observed among patients undergoing dialysis. Detection systems for serum HCV antibodies are insensitive in the acute phase because of the long serological window. Direct detection of HCV depends on PCR test but this test is not suitable for routine screening. The objective of this study was to determine prevalence of HCV, genotyping and if HCV core antigen test could be a better alternative to NAT techniques for the diagnosis of HCV infection during the window period and whether the sensitivity for antibody detection is preserved.

Methods: Current study includes screening of 159 patients on long-term dialysis by HVC antibodies test, PCR HCV-RNA and $\mathrm{HCV}$ core antigen test by commercial tests.

Results: The prevalence of HCV was $10.7 \%$ (17 patients) and genotype 4 was the most common one (64.7\%). The sensitivity of $\mathrm{HCV}$ core antigen test was $94.1 \%$, the specificity $100 \%$, the positive predictive power $100 \%$, and the negative predictive power 97.9\%. In conclusions; patients on maintenance HD in Yemen have a high prevalence of HCV infection comparing with general population; and genotype 4 is predominant.

Conclusion: The performance of serological detection of HCV core antigen was better than that of HCV antibodies test and may be an alternative to nucleic acid amplification technology (NAT) for routine monitoring of patients on chronic dialysis.

Keywords: Genotype, Haemodialysis, Hepatitis C virus, HCV core antigen, HCV antibodies, PCR HCV-RNA, Yemen.

Article Info: Received 4 March 2019; Revised 3 April; Accepted 6 May, Available online 15 May 2019

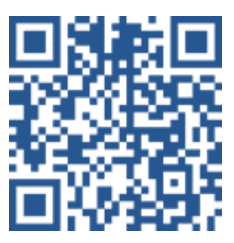

Cite this article-

Hanash SH, Al-Shamahy HA, Bamshmous MHS. Prevalence and genotyping of hepatitis C virus in hemodialysis patients and evaluation of HCV-core antigen test in screening patients for dialysis in Sana'a city, Yemen. Universal Journal of Pharmaceutical Research 2019; 4(2): 14-18.

DOI: https://doi.org/10.22270/ujpr.v4i2.251

Address for Correspondence

Prof. Hassan A. Al-Shamahy, Faculty of Medicine and Heath Sciences, Sana'a University, P.O. Box 775 Sana'a, Yemen. Phone: +967-770299847, E-mail: shmahe@yemen.net.ye

\section{INTRODUCTION}

An estimated 143 million people (2\%) worldwide are infected with hepatitis C as reported in $2015^{1}$. In 2013 about 11 million new cases occurred ${ }^{1}$. It occurs most commonly in Africa and Central and East Asia. About 167,000 deaths due to liver cancer and 326,000 deaths due to cirrhosis occurred in 2015 due to hepatitis $C^{2}$.

In Yemen $\mathrm{HCV}$ antibodies among general community showed a steady decline to less than $0.5 \%{ }^{3,4}$, however among HCV risk groups such as dental workers and public health center workers, it was $5.5 \%$ and $11.5 \%$ respectively ${ }^{5,6}$. Limited information is available among patients for dialysis in Yemen. HCV infection is more common among patients for dialysis than in healthy populations worldwide. The Dialysis Outcomes and Practice Patterns Study (DOPPS) reported a general prevalence of 13.5 percent among adult hemodialysis patients randomly selected from 308 dialysis services in developed countries (France, Germany, Italy, Japan, Spain, the United Kingdom, and the United States) ${ }^{7}$. A study from Australia and New Zealand ${ }^{8}$ in HD patients $(n=23,046)$ reported an independent and significant association between anti-HCV positive serologic status and all-cause mortality over a 10-year follow up (HR, $1.25,95 \%$ CI $1.07-1.46, P=0.004)$. Regardless of the control of blood products, $\mathrm{HCV}$ transmission is stationary being observed among HD patients. HCV infection diagnosis is usually rooted in the detection of 
an anti-HCV antibody, while it goes undetected in the first 4-6 weeks of infection (so-called window period). Furthermore, patients positive for anti-HCV antibody include both those who are actively infected and those who have recovered from infection'. Kidney Disease Improving Global Outcomes (KDIGO) clinical practice guidelines for the prevention, diagnosis, evaluation, and treatment of hepatitis $\mathrm{C}$ in chronic kidney disease ${ }^{10}$ recommended the use of nucleic acid amplification technology (NAT). A quantitative HCV core antigen (HCVcAg) test has been developed for the confirmation of viremia in patients with hepatitis $\mathrm{C}$. This test can detect total nucleo-capsid core antigen whose sequence is highly conserved across HCV genotypes. A number of studies in the general population have highlighted the importance of $\mathrm{HCV}$ core antigen detection as an alternative to NAT for early diagnosis of infection, as direct marker of viral replication in chronic phase of infection and as relevant marker for predicting and monitoring the response to therapy ${ }^{11}$. Few studies exist about the efficacy of HCV core antigen test in patients on chronic HD in the early diagnosis of HCV infection ${ }^{12-14}$. The objective of this study was to determine prevalence of $\mathrm{HCV}$, genotyping and if $\mathrm{HCV}$ core antigen test could be better an alternative to NAT techniques for the diagnosis of $\mathrm{HCV}$ infection during the window period and whether the sensitivity for antibody detection is preserved.

\section{SUBJECTS AND METHODS}

The study was performed in the haemodialysis units of Al-Thorah hospital. A total of 159 patients were enrolled in this cross sectional study in 2016; patients gave informed consent and thus the whole patient population were investigated. All patients underwent chronic haemodialysis treatment for end stage renal disease during the study period. The laboratory tests were conducted in Al-Awalagy Medical laboratory. Anti-HCV antibody was measured by a third generation commercial ELISA (Enzymun-Test Anti$\mathrm{HCV}$; Boehringer Mannheim, Germany). The third generation assay detects antibodies for three viral antigens (c22-3, c200, and NS5). HCV-RNA and viral genotype were assessed using PCR. All tests were carried out and interpreted strictly in accordance with the manufacturer's instructions.

\section{Statistical Analysis}

The performance of the HCV core antigens and antibodies HCV test were done by comparing to HCVRNA PCR test. The following parameters were calculated: sensitivity $\%$, Specificity $\%$, false positive $\%$ (FP), false negative\% (FN), positive predictive value (PPV); and negative predictive value (NPV). Gender and age groups which are possible associated risk factors for $\mathrm{HCV}$ infection were assessed. The data were examined in a case-control study format. For HCV, persons with evidence of previous or current infection with $\mathrm{HCV}$ were matched up with those who were $\mathrm{HCV}$ negative.

\section{Ethical Consideration}

Ethical clearance for the study was taken from the Faculty of Medicine and Health Sciences Research Review Committee. Informed Consent was taken from the volunteers before the collecting specimens and file questionnaire.

Table 1: The prevalence rate of HCV ribonucleic acid (RNA), and associated odds ratio for different sex and age of a sample of hemodialysis patients.

\begin{tabular}{|c|c|c|c|c|c|c|}
\hline \multirow[t]{2}{*}{ Characters } & \multicolumn{2}{|c|}{$\begin{array}{c}\text { Positive } \\
\text { HCV } n=17\end{array}$} & \multirow[t]{2}{*}{ OR } & \multirow[t]{2}{*}{ CI } & \multirow[t]{2}{*}{$\chi^{2}$} & \multirow[t]{2}{*}{$P$} \\
\hline & No. & $\%$ & & & & \\
\hline \multicolumn{7}{|l|}{ Sex } \\
\hline Male $n=56$ & 8 & 14.3 & 1.7 & $0.6-4.7$ & 1.16 & 0.27 \\
\hline Female $\mathrm{n}=103$ & 9 & 8.7 & 0.67 & $0.21-2.2$ & 0.57 & 0.45 \\
\hline \multicolumn{7}{|l|}{ Age groups } \\
\hline$<20$ Yrs n $=13$ & 1 & 7.7 & 0.73 & $0.11-5.2$ & 0.09 & 0.76 \\
\hline $20-29$ Yrs $n=35$ & 2 & 5.7 & 0.5 & $0.1-2.4$ & 0.41 & 0.33 \\
\hline $30-39$ Yrs $n=23$ & 2 & 8.7 & 0.83 & $0.12-4.3$ & 0.06 & 0.81 \\
\hline $40-49$ Yrs $n=22$ & 3 & 13.6 & 1.5 & $0.3-6.4$ & 0.36 & 0.54 \\
\hline$>49$ Yrs $n=66$ & 9 & 13.6 & 1.6 & $0.6-4.6$ & 1.02 & 0.31 \\
\hline $\begin{array}{l}\mathrm{n}=159 \\
\text { crude rate }\end{array}$ & 17 & 10.7 & & & & \\
\hline
\end{tabular}

OR-Odds ratio $\geq 1$ is at risk of infection, CI-Confidence intervals; $\chi 2$-Chi-square $\geq 3.83$ is significan $p$-Probability value $\leq 0.05$ is significant

\section{RESULTS}

Table 1 shows the prevalence rate of HCV ribonucleic acid (RNA), and associated odds ratio for different sex and age of a sample of hemodialysis patients in Sana'a city. The prevalence rate of HCV among HD patients was $10.7 \%$, for male patients was $14.3 \%$, higher than $8.7 \%$ for female patients. When age was considered, there was an increasing trend of HCV infection with increasing age. The genotype distribution in $17 \mathrm{HCV}$ positive patients is shown in Table 2. Overall, HCV genotype 4 was the most predominant genotype $(64.7 \%)$ followed by genotype $1 \mathrm{a}$ and $1 \mathrm{~b}(29.4 \%)$ and 2a $(5.9 \%)$. Table 3 shows the prevalence rate of different HCV markers in 159 haemodialysis patients in Sana'a city. Seventeen HD patients were HCV ribonucleic acid (RNA) positive, 14 HD patients were $\mathrm{HCV}$ antibodies positive and $16 \mathrm{HD}$ patients were HCV core proteins positive. Table 4 shows the performance of $\mathrm{HCV}$ antibodies test and HCV Core protein test compared to $\mathrm{HCV}$ ribonucleic acid (RNA) 
among haemodialysis patients in Sana'a city. The sensitivity of $\mathrm{HCV}$ core antigen test was $94.1 \%$, the specificity $100 \%$, the positive predictive power $100 \%$, the negative predictive power $97.9 \%$, false positive rate $0.0 \%$ and false negative rate $5.9 \%$. However less reliable results were found for $\mathrm{HCV}$ antibodies test in which the sensitivity of $\mathrm{HCV}$ antibodies test was $70.6 \%$, the specificity $98.9 \%$, the positive predictive power $100 \%$, the negative predictive power $97.9 \%$ false positive rate $1.41 \%$ and false negative rate $29.4 \%$.

Table 2: The prevalence of different $\mathrm{HCV}$ genotyping among HCV HD patients.

\begin{tabular}{lcc}
\hline Genotypes & Number & \% \\
\hline Genotype 1a+1b & 5 & 29.4 \\
Genotype 2a & 1 & 5.9 \\
Genotype 4 & 11 & 64.7 \\
Genotype 3a & 0 & 0 \\
Genotype 5 & 0 & 0 \\
Genotype 6 & 0 & 0 \\
Total & 17 & 100 \\
\hline
\end{tabular}

\section{DISCUSSION}

Information on the prevalence of $\mathrm{HCV}$ in the general population and in the various high risk groups such as HD patients, prevalence of genotypes and evolution of tests used for screening $\mathrm{HCV}$ are important in the prevention and control HBV infections. Unfortunately, there is little information available on these topics, particularly from Middle East countries and more specifically from Yemen. HCV infection continues to be the most frequently recognized cause of liver damage in CKD patients ${ }^{15}$.

Table 3: The prevalence rate of different $\mathrm{HCV}$ markers in 159 haemodialysis patients. Tests HCV ribonucleic acid Total $\frac{\text { (RNA) }}{\text { Positive Negative }}$

\begin{tabular}{|c|c|c|c|}
\hline \multicolumn{4}{|c|}{ HCV antibodies } \\
\hline Positive & 12 & 2 & 14 \\
\hline Negative & 5 & 140 & 145 \\
\hline \multicolumn{4}{|c|}{ HCV core proteins } \\
\hline Positive & 16 & 0 & 16 \\
\hline Negative & 1 & 142 & 143 \\
\hline Total & 17 & 142 & 159 \\
\hline
\end{tabular}

Although a severe clinical course of HCV-related liver disease seems unusual in most HD patients and cirrhosis is an infrequent event among dialysis patients, longitudinal studies have found an independent and significant relationship between anti-HCV antibody positivity and reduced patient survival ${ }^{16,17}$. The Dialysis Outcomes and Practice Patterns Study (DOPPS) on HD patients in three continent ${ }^{18}$ had reported an independent and significant association between positive anti-HCV antibody and mortality risk (adjusted relative risk, 1.17; $P<0.0159$ ).

Table 4: The performance of HCV antibodies test and HCV Core protein test comparing to HCV ribonucleic acid (RNA) among haemodialysis patients in Sana'a city.

\begin{tabular}{lcccccc}
\hline Evaluated tests & Sensitivity & Specify \% & FP \% & FN\% & PPV\% & NPV\% \\
\hline ELISA HCV antibodies & 70.6 & 98.9 & 1.41 & 29.4 & 85.7 & 96.6 \\
ELISA HCV core protein & 94.1 & 100 & 0.0 & 5.9 & 100 & 97.9
\end{tabular}

(core antigen)

Sensitivity: Probability that test will be positive, given the patient is disease. Specify: Probability that the test will be negative, given the patient is disease free. $\mathrm{FP}=$ false positive: Probability that test will be positive; known the patient is disease free. FN= false negative: Probability that test will be negative, known the patient is diseased. PPV= positive predictive value: Probability that a patient is diseased, given a positive test. $\mathrm{NPV}=$ negative predictive value: Probability that a patient disease free, given a negative test.

Fabrizi et al., ${ }^{19}$ showed that $\mathrm{HCV}$-seropositive HD patients had higher rates of liver disease-related death than their sero-negative matching parts, but that cardiovascular and infectious disease related mortality rates were similar ${ }^{19}$. Ohsawa et al., showed that seropositivity for anti-HCVcAg is independently associated with increased all-cause, cardiovascular, and liver disease related mortality in HD patients ${ }^{20}$. In the current study in Yemen the prevalence rate of $\mathrm{HCV}$ among HD patients was $10.7 \%$, (male rate $=14.3 \%$, female rate $=8.7 \%$ ). This result is indicative that $\mathrm{HCV}$ infection is more common in dialysis patients in Yemen than in healthy populations $(0.5-5 \%)^{3-5}$. The current result also is slightly lower than the Dialysis Outcomes and Practice Patterns Study (DOPPS) which reported an overall prevalence of $13.5 \%$ among adult hemodialysis patients randomly selected from 308 dialysis facilities in developed countries ${ }^{7}$.

In addition, current study results show that $\mathrm{HCV}$ genotype 4 is the predominant genotype (64.7\%) among Yemeni patients followed by $1 \mathrm{a}$ and $1 \mathrm{~b}(29.4 \%)$ and $2 \mathrm{a}(5.9 \%)$. This data is similar to that reported in Middle East countries, and previously in the Yemen; where genotype 4 is predominant ${ }^{4,21-24}$. It is important to diagnose a hepatitis $\mathrm{C}$ virus infection in the acute phase in order to reduce the incidence of this infection in high-risk populations like HD patients ${ }^{25}$. Biochemical evaluation of $\mathrm{HCV}$ infection in patients with CKD is inaccurate.

Serum aminotransferase values are typically lower in dialysis patients than the non-uremic populations ${ }^{26}$. Thus we carried out this study to evaluate the performance of $\mathrm{HCV}$ antibodies test and $\mathrm{HCV}$ Core protein test comparing to $\mathrm{HCV}$ ribonucleic acid (RNA) among haemodialysis patients (Table 4). The sensitivity of HCV core antigen test was $94.1 \%$, the specificity $100 \%$, the positive predictive power $100 \%$, the negative predictive power $97.9 \%$, false positive rate $0.0 \%$ and false negative rate $5.9 \%$. However less reliable results were found for $\mathrm{HCV}$ antibodies test in which the sensitivity of $\mathrm{HCV}$ antibodies test was $70.6 \%$, the specificity $98.9 \%$, the positive predictive power $100 \%$, the negative predictive power $97.9 \%$ false positive rate $1.41 \%$ and false negative rate $29.4 \%$. Current results are similar to that reported previously in which detection systems for serum HCV antibodies are 
insensitive in the acute phase because of the long serological window ${ }^{7}$. Also, the direct detection of HCV depends on NAT techniques with several problems: frequent unavailability, considerable skill requirement, limited reproducibility, and overall important costs. HCV detection by PCR-RNA, although widely accepted as a gold standard test in the diagnosis of HCV infection in CKD patients, it is not suitable for routine screening ${ }^{7}$. Thus from current results $\mathrm{HCV}$ core antigen quantification assay has proved useful for an early diagnosis of $\mathrm{HCV}$ infection in community-based and in dialysis populations. Also, $\mathrm{HCV}$ core antigen may be an alternative to HCV-RNA detection, since no subjects, who were negative for $\mathrm{HCV}$ core antigen, were positive for HCV-RNA (false negative $=0.0 \%$ ). Current result is similar to that reported in a large population-based cohort studies by Ohsawa et al., ${ }^{27}$; and by Kato et al., ${ }^{28}$ in which no subjects, who were negative for $\mathrm{HCV}$ core antigen, were positive for HCV-RNA; also Ohsawa et al. ${ }^{27}$ and Kato et al., ${ }^{28}$ suggests that detection of HCV core antigen combined with anti-HCV antibody is useful in predicting long-term survival prognosis of persistent $\mathrm{HCV}$ infection in HD patients. Finally, from current study experience HCV core antigen test is both a costeffective (a single sample has a $40 \$$ charge for PCR HCVRNA and a $5 \$$ charge for HCV core antigen test) and a less labour-intensive alternative to NAT tests. These features make it a routine assay useful for chronic dialysis treatment patients.

\section{CONCLUSION}

Patients on maintenance HD in Yemen have a high incidence and prevalence of $\mathrm{HCV}$ infection and genotype 4 is the predominant one. Serological detection of HCV core antigen may be an alternative to NAT techniques for routine monitoring of patients on chronic dialysis towards the prevention of HCV spread. $\mathrm{HCV}$ core antigen is an accurate marker for early identification of $\mathrm{HCV}$ infection; it can improve virological monitoring and integrate the diagnosis of acute hepatitis $\mathrm{C}$ in dialysis population. The minimal cost and its easiness make this assay useful for routine long-term dialysis treatment patients. Furthermore, screening for HCV antibodies alone does not exclude infection with $\mathrm{HCV}$.

\section{ACKNOWLEDGEMENTS}

The authors would like to acknowledge Sana'a University and Awalagy Medical laboratory, Sana'a city, Yemen.

\section{AUTHOR'S CONTRIBUTION}

This research work is part of A MSc. thesis. The candidate is the third author (MSB) who conducted the laboratory and field works; and wrote up the thesis. The corresponding author (HAA) supervised the laboratory and field works, revised and edited the thesis draft and the manuscript and $\mathrm{SHH}$ revised and edited the thesis and the article.

\section{CONFLICT OF INTEREST}

No conflict of interest associated with this work.

\section{REFERENCES}

1. GBD. "Global, regional, and national incidence, prevalence, and years lived with disability for 310 diseases and injuries, 1990-2015: a systematic analysis for the Global Burden of Disease Study 2015". Lancet 2016; 388 (10053): 15451602.

2. WHO. "Hepatitis C Fact sheet $\mathrm{N}^{\circ} 164 "$. WHO. July 2015. Archived from the original on 31 January 2016.

3. Al-Nabehi BAH, Al-Shamahy H, WSE Saeed, AM Musa, AM El Hassan,. Sero-molecular epidemiology and risk factors of viral hepatitis in Urban Yemen. Int J Virol 2015; 11 (3), 133-138. https://doi.org/10.3923/ijv.2015.133.138

4. Al-Shamahy HA, Abdu SSA. Genotyping of Hepatitis C Virus (HCV) in infected patients from Yemen. Eur J Basic Med Sci 2014; 3 (4):78-82. https://doi.org/10.15197/sabad.2.3.15

5. Al-Kebsi A, Othman A, Abbas AK, Madar E, Al-Shamahy H, Al-Gaffari K, Daname SM, Motareb F. Sero-prevalence of hepatitis $\mathrm{C}$ virus among dental clinic workers in Sana'a city-Yemen and the risk factors contributing for its infection. Univ J Pharm Res 2017; 2(5): 28-33. http://doi.org/10.22270/ujpr.v2i5.R6

6. Al-Marrani WHM, Al-Shamahy HA. Prevalence of HBV and $\mathrm{HCV}$; and their associated risk factors among public health center cleaners at selected Public Health Centers in Sana'a city-Yemen. Univ J Pharm Res 2018; 3(5): 63-67. https://doi.org/10.4236/ojmm.2015.53017

7. Michel J, Paul M. Hepatitis $\mathrm{C}$ treatment in chronic kidney disease patients: The Kidney Disease Improving Global Outcomes Perspective. Blood Purif 2017; 43:206-209. https://doi.org/10.4236/ojmm.2015.53017

8. Scott DR, Wong JKW, Spicer TS, et al. Adverse impact of hepatitis $\mathrm{C}$ virus infection on renal replacement therapy and renal transplant patients in Australia and New Zealand. Transplantation 2010; 90(11):1165-1171. https://doi.org/10.1097/TP.0b013e3181f92548

9. Laperche S, Le Marrec N, Girault A, et al. Simultaneous detection of hepatitis $\mathrm{C}$ virus (HCV) core antigen and anti$\mathrm{HCV}$ antibodies improves the early detection of $\mathrm{HCV}$ infection. J Clin Micro 2005; 43(8):3877-3883. https://doi.org/10.1128/JCM.43.8.3877-3883.2005

10. KDIGO clinical practice guidelines for the prevention, diagnosis, evaluation, and treatment of hepatitis $\mathrm{C}$ in chronic kidney disease. Kidney International. 2008; 73:S1-S99.

11. Veillon P, Payan C, Picchio G, Maniez-Montreuil M, Guntz $\mathrm{P}$, Lunel F. Comparative evaluation of the total hepatitis C virus core antigen, branched-DNA, and amplicor monitor assays in determining viremia for patients with chronic hepatitis $\mathrm{C}$ during interferon plus ribavirin combination therapy. J Clin Microbiol. 2003; 41(7):3212-3220. https://doi.org/10.1128/JCM.41.7.3212-3220.2003

12. Fabrizi F, Lunghi G, Aucella F, et al. Novel assay using total hepatitis $\mathrm{C}$ virus (HCV) core antigen quantification for diagnosis of $\mathrm{HCV}$ infection in dialysis patients. J Clin Micro 2005; 43(1):414-420. https://doi.org/10.1128/JCM.43.1.414-420.2005

13. Bouzgarrou N, Fodha I, Ben Othman S, et al. Evaluation of a total core antigen assay for the diagnosis of hepatitis $\mathrm{C}$ virus infection in hemodialysis patients. J Med Virol 2005; 77(4):502-508. https://doi.org/10.1002/jmv.20485

14. Miedouge M, Saune K, Kamar N, Rieu M, Rostaing L, Izopet J. Analytical evaluation of HCV core antigen and interest for HCV screening in haemodialysis patients. J Clin Virol 2010; 48(1):18-21. https://doi.org/10.1016/j.jcv.2010.02.012

15. Stehman-Breen CO, Emerson S, Gretch D, Johnson RJ. Risk of death among chronic dialysis patients infected with hepatitis C virus. American J Kidney Dis 1998; 32(4):629634. https://doi.org/10.1016/S0272-6386(98)70027-7

16. Nakayama E, Akiba T, Marumo F, Sato C. Prognosis of antihepatitis $\mathrm{C}$ virus antibody-positive patients on regular hemodialysis therapy. J American Soc Nephrol 2000; 11(10):1896-1902. 
17. Espinosa M, Martin-Malo A, De Lara MAA, Aljama P. Risk of death and liver cirrhosis in anti-HCV-positive long-term haemodialysis patients. Nephrol Dial Trans 2001; 16(8):1669-1674. https://doi.org/10.1093/ndt/16.8.1669

18. Goodkin DA, Bragg-Gresham JL, Koenig $\mathrm{KG}$, et al. Association of comorbid conditions and mortality in hemodialysis patients in Europe, Japan, and the United States: the Dialysis Outcomes and Practice Patterns Study (DOPPS). J American Soc Nephrol 2003; 14(12):32703277.https://doi.org/10.1097/01.ASN.0000100127.54107.57

19. Fabrizi F, Takkouche B, Lunghi G, Dixit V, Messa P, Martin $P$. The impact of hepatitis $C$ virus infection on survival in dialysis patients: meta-analysis of observational studies. $\mathrm{J}$ Viral Hepat 2007; 14(10):697-703.

https://doi.org/10.1111/j.1365-2893.2007.00868.x

20. Ohsawa M, Kato K, Tanno K, et al. Seropositivity for anti$\mathrm{HCV}$ core antigen is independently associated with increased all-cause, cardiovascular, and liver disease-related mortality in hemodialysis patients. J Epidem. 2011; 21(6):491-499. https://doi.org/10.2188/jea.JE20100187

21. Osaba AO. Hepatitis C virus genotypes in Saudi Arabia. Saudi Med J 2002; 23(1): 7-12. https://doi.org/10.5144/0256-4947.2013.1

22. Mohammed M, Ali M. Genotyping of Hepatitis C virus (HCV) in infected patients from Saudi Arabia. African J Microbiol Res 2011; 5(16): 2388-2390. https://doi.org/10.11604/pamj.2014.19.69.4580
23. Bdour S. Hepatitis $\mathrm{C}$ virus infection in Jordanian hemodialysis units, serological diagnosis and genotyping. J Med Microbiol 2002; 51(8):700-4. https://doi.org/10.1099/0022-1317-51-8-700

24. Al Balwi MA. Prevalence of mixed hepatitis $\mathrm{C}$ virus (HCV) genotypes among recently diagnosed dialysis patients with HCV infection. Saudi J Kidney Dis Transplant 2011; 22(4):712-6.

25. Di Napoli A, Pezzotti P, Di Lallo D, Petrosillo N, Trivelloni C, Di Giulio S. Epidemiology of hepatitis $\mathrm{C}$ virus among long-term dialysis patients: a 9-year study in an Italian region. American J Kid Dis. 2006; 48(4):629-637. https://doi.org/10.1053/j.ajkd.2006.07.004

26. Fabrizi F, Dixit V, Messa P, Martin P. Hepatitis C- related liver disease in dialysis patients. In: Morales JM, editor. Hepatitis $\mathrm{C}$ in renal disease, hemodialysis and transplantation. contributions to nephrology. Basel, Switzerland: Karger; 2012; 176:42-53. https://doi.org/10.1159/000332379

27. Ohsawa M, Kato K, Itai K, et al. Standardized prevalence ratios for chronic hepatitis $\mathrm{C}$ virus infection among adult Japanese hemodialysis patients. J Epidemiol. 2010; 20(1):30-39. https://doi.org/10.2188/jea.JE20090043

28. Kato A, Takita T, Furuhashi M, Fujimoto T, Suzuki H, Maruyama Y. Association of $\mathrm{HCV}$ core antigen seropositivity with long-term mortality in patients on regular hemodialysis. Nephron Extra 2012; 2:76-86. https://doi.org/10.1159/000337333 